\title{
Popularizing Radical Ideas in the Dutch Art World of the Early Eighteenth Century: Willem Goeree (1635-1711) and Arnold Houbraken (166o-1719)
}

\author{
Jonathan Israel
}

\begin{abstract}
In this chapter I identify radical and spinozist traits in the works of Willem Goeree and Arnold van Houbraken. In many respects these men were, as publishers, booksellers, and graphic artists, in the same line of business as Romeyn de Hooghe, but they appear to have been much more radical. I show how both were also, like De Hooghe, 'civic intellectuals' fond of a "distinctively lay kind of vernacular, non-academic erudition." I offer a finely drawn tour d'horizon of the cultural milieu in which these men moved, a milieu that included fellow artists and renowned scholars as well as ministers, rabbis, and radical thinkers. I infer new connections between their art theory, in which they strongly foregrounded close observation of the object and 'naturalness,' and the ideas of Spinoza, Bekker, and Van Leenhof-Reformed synods identified both Goeree and Houbraken as nefarious defenders of such ideas. I argue that this may have made them a connecting link between the early phase of the radical Enlightenment and the libertinage érudit of the Huguenot refugees from the second quarter of the eighteenth century.
\end{abstract}

There are grounds to include among the ranks of the early-eighteenth-century Dutch radical Enlightenment two connected, and hitherto rather neglected, figures - the publisher, antiquarian, and writer on art Wilhelmus Goeree (1635-1711) and the Dordrecht artist and art critic Arnold Houbraken (166o1719). ${ }^{1}$ Goeree was something of a living link between the founding generation of the cercle spinoziste of the 1650 and 1660 s and the early eighteenth century. He himself reports that he had frequented and dined "more than once" with Franciscus van den Enden (1602-74), the young Spinoza's Latin master who, at an earlier stage in his life, had been active as an art dealer in Amsterdam.

1 This contribution is a reworked, expanded version of Jonathan Israel, 'Spinozistic Popular Radicalism in the Dutch Art World of the Later Golden Age,' in: De tienduizend dingen: Feestbundel voor Reinier Salverda, ed. Hanno Brand (Leeuwarden, 2013), pp. 129-44.

(C) JONATHAN ISRAEL, 2019 | DOI:10.1163/9789004389397_011

This is an open access chapter distributed under the terms of the prevailing CC-BY-NC License at the time of publication. 
Arnold Houbraken was the author of the Groote Schouburgh der Nederlantsche Konstschilders en Schilderessen (The Great Theatre of Dutch Painters and Women Painters, 1718-21), a compendium that has been accounted the "first extensive study made of the lives and works of 17 th century Netherlandish painters." ${ }^{2}$ Houbraken trained as an artist during $1674-8$ in Dordrecht with Rembrandt's pupil Samuel van Hoogstraten (1627-78), author of the Inleydinge tot de Hooge Schole der Schilderkonst (1678), and, to an even greater extent than Goeree, amassed an extensive and detailed knowledge of the Dutch art world of his own day and the recent past. These two critics both figured prominently among the just twelve writers active between 1600 and 1750 in the Netherlands who can be said to have written 'extensively' on the topic of Dutch Golden Age art. ${ }^{3}$ Their remarkable careers and writings pose the question of the relation between Dutch Golden Age art as a sphere of cultural expression and spinozist radical thought at the turn of the eighteenth century.

Conceivably, Goeree and Houbraken barely knew each other personally even though both were renowned art connoisseurs and habitués of the art world of their time, since Houbraken moved permanently to Amsterdam, from Dordrecht, only in 1709, prompted by the Amsterdam regent and art collector, Johan Witsen, a key patron, little more than a year before Goeree's death in early 1711. However that may be, these two personalities had much in common, being noted writers on art and prominent representatives of a distinctive new type of early Enlightenment Dutch civic intellectual culture. Both authors, furthermore, acquired somewhat dubious reputations as freethinkers, albeit neither acquired quite the notoriety of the engraver Romeyn de Hooghe (16451708), who became especially infamous among late Golden Age Dutch artists as a libertine and "een spotter met Godt en sijn woordt" (one who mocks God and his Word). ${ }^{4}$ Both read widely, evincing strong views on numerous controversial topics, and stood out as eager amateur experts in classical antiquity, classicism, and ancient history, showing a fondness for a distinctively lay type of vernacular, non-academic erudition. Houbraken, who also had a liking for the aphorisms of the seventeenth-century Spanish Golden Age Stoic moralist Balthasar Gracián, has been called a "Stoic Deist" and a proponent of "deistic classicism" who believed God created the world according to a plan hidden in nature. ${ }^{5}$

2 Seymour Slive, Rembrandt and His Critics 1630-1730 (The Hague, 1953), p. 177.

3 Paul Taylor, Dutch Flower Painting 1600-1720 (New Haven, Conn., 1995), p. 77.

4 Inger Leemans, 'De Viceroy van de hel: Radicaal libertinisme,' in: Romeyn de Hooghe: De Verbeelding van de late Gouden eeuw, ed. Henk van Nierop et al. (Zwolle, 2008), pp. 32-47, there $34-5$.

5 See Hendrik J. Horn, The Golden Age Revisited: Arnold Houbraken's Great Theatre of Netherlandish Painters and Paintresses, 2 vols. (Doornspijk, 200o) and Eva Boom's review of Horn's book in Oud Holland 115, nos. 3/4 (2001-2), 235-7. 
Both writers, as we shall see, were vocal defenders of Balthasar Bekker (1634-98), the Frisian preacher whose views on magic, Satan, and demonology, as well as the method of Bible interpretation, were emphatically condemned by the North Holland Synod at Alkmaar in July 1692. Bekker's celebrated book De Betoverde Weereld (The World Bewitched, 1691-3), generating what was perhaps the greatest Dutch public intellectual commotion of the age, came close to being banned in Holland and was actually prohibited by the States of Utrecht. ${ }^{6}$ Beside their dogged Bekkerite allegiance, both personalities publicly sympathized with the embattled Zwolle preacher and clandestine spinozist Frederik van Leenhof (1647-1713). Expressing support for Van Leenhof in print was unusual during the opening decade of the eighteenth century and distinctly courageous in the wake of the vehement hue and cry against that renegade preacher (no less fierce and prolonged than that against Bekker).

In this latter connection, it is noteworthy that Willem's son Jan Goeree (1670-1731), born in Middelburg and figuring among the foremost engravers and book illustrators of the early eighteenth century, executed an elaborate depiction of Solomon's Temple signed 'J. Goeree del. et fecit' as the frontispiece to the now rather rare Amsterdam edition of Van Leenhof's book 't Leven van Salomon en zyn bewys der Ydelheden (The Life of Solomon and his Proof of the Vanities), published in 1700, a work treating Solomon's wisdom as a wholly natural phenomenon without any supernatural or miraculous component. ${ }^{7}$ Both here and in his De Prediker van den wijzen en magtigen konink Salomon (The Preacher of the Wise and Powerful King Solomon, 1700) Van Leenhof used the figure of King Solomon "in part to throw all other kings into the least favourable and most dubious light possible,"8 but also to echo Spinoza's 'Solomon' as an iconic figure, holding that only true wisdom teaches us to fear

6 Jonathan Israel, The Dutch Republic: Its Rise, Greatness and Fall, 1477-1806 (Oxford, 1995), pp. 925-30.

7 Frederik van Leenhof, 't Leven van Salomon en zyn bewys der Ydelheden (Amsterdam, 1702); this is a different work from the better-known Frederik van Leenhof, Het Leven van den wijzen en magtigen Koninck Salomon (Amsterdam, 1700); a copy of the first is to be found in the Carl Gebhardt collection of Columbia University Library, New York; Jan Goeree became guild member as a book and art dealer in Amsterdam only in 1713. See I. H. van Eeghen, De Amsterdamse boekhandel 1680-1725, 5 vols. (Amsterdam, 1960-78), 4: 162. On the role of King Solomon in the work of Spinoza and in Van Leenhof, see Jonathan Israel, 'Spinoza, King Solomon and Frederik van Leenhof's Spinozistic Republicanism,' Studia Spinozana 11 (1995), 303-17; Jonathan Israel, 'The Democratic Republicanism of Frederik van Leenhof,' in: Dall' origine dei Lumi alla Rivoluzione. Scritti in onore di Luciano Guerci e Giuseppe Ricuperati, ed. D. Balani et al. (Rome, 2008), pp. 265-80.

8 Israel, 'Democratic Republicanism' (see above, n. 7), 267. 
God properly and cultivate true religion: "hoc est, vera religione colere."9 For Spinoza, Solomon was the Biblical emblem of personal enlightenment. It is in man's intellect, according to Spinoza's 'Solomon,' that men find the source of their happiness, tranquillity, and blessedness: "thus, in Solomon's view also, the happiness and peace of the person who cultivates natural understanding chiefly depend not on the realm of fortune (i.e. the external assistance of God), but upon their own internal power (or the internal assistance of God), because they preserve themselves best by alertness, action and good counsel." ${ }^{\prime 10}$ Willem Goeree, an avid collector of architectural models and drawings, had long nurtured a special fascination for the topic of Solomon's Temple." Both Willem and Jan Goeree, a prolific artist who executed all manner of illustrations for publishers and authors, showing a particular gift for historical scenes and classicizing allegories, must have been personally familiar with Van Leenhof, who besides being a major theological subversive possessed an outstanding and well-advertised art collection on display at his house in Zwolle. Willem's connections with the art world extended throughout the Netherlands, as did his reputation for stalwart anti-Orangism in politics and anti-Voetianism in theology, first acquired during the noisy furore in Zeeland in 1676, when Stadholder William III ejected the Cocceian preacher Wilhelmus Momma (1642-77) from Middelburg. ${ }^{2}$ But in addition he was a publisher and had published, among other texts, Van Leenhof's best-known early work, De Keten der Bybelsche God-Geleertheyt (The Chain of Biblical Theology, 1678), in which hints of spinozism were later spotted by the Zwolle preacher's numerous adversaries. The title page of the 1684 reprint of De Keten identifies its Amsterdam publisher as "Wilhelmus Goeree op de Leidse Straat."

Willem Goeree was born in 1635, just three years after Spinoza, and departed this world on 3 May $1711,^{13}$ at a time when the Van Leenhof controversy still raged unresolved. Owing to the early death of his own father, Hugo Willemsz. Goeree (dates unknown), an eminent Middelburg physician, and the family's subsequent straightened circumstances, the young Goeree was deprived of the opportunity to study at a university. Hugo Goeree was also a keen

Benedict de Spinoza, Opera, ed. Carl Gebhardt, 4 vols. (Heidelberg, 1925), 2: 66-7; Wim Klever, Een nieuwe Spinoza in veertig facetten (Amsterdam, 1995), p. 14; Israel, 'Democratic Republicanism' (see above, n. 7), p. 272.

10 Benedict de Spinoza, Theological-Political Treatise, ed. Jonathan Israel (Cambridge, 2007), p. 67; Graeme Hunter, Radical Protestantism in Spinoza's Thought (Aldershot, 2005), p. 53.

11 Charles van den Heuvel, 'Willem Goeree (1635-1711) en de ontwikkeling van een algemene architectuurtheorie in de Nederlanden,' Bulletin Koninklijke Nederlandse Oudheidkundige Bond 5 (1997) 154-76, there $155,167-8$.

Van den Heuvel, 'Willem Goeree' (see above, n. 11), 156; Israel, Dutch Republic (see above, n. 6), pp. 820, 898 .

13 Frederik Nagtglas, Levensberichten van Zeeuwen, 2 vols. (Middelburg, 1890-1893), 1: 271. 
amateur theologian specializing in Bible study who had frequently conferred, as Goeree recounts in his preface to his French edition of Petrus Cunaeus's famous work, De republica hebraeorum (1617), with the Sephardic rabbi Jacob Judah Leon 'Templo' (1603-75) whilst the latter resided in Middelburg as rabbi in the house-synagogue of the Sephardic merchant Paolo Jacomo (Jacob Jessurun) de Pinto. ${ }^{14}$ Cunaeus's work, which appeared in eight Latin editions before Goeree published it in French translation in 1705, was noted for arguing that the laws of the ancient Hebrews were superior to those of the Greeks and Romans, a point later disputed by the celebrated Huguenot érudit Jacques Basnage. ${ }^{15}$ Over many years, Jacob Judah had worked on and exhibited his celebrated model of the Temple of Solomon, renowned during the 1640 s and 1650 in England as well as the Netherlands. This much-discussed model was based on a grandiose engraved conception of the Temple in Jerusalem published in 1604 by the Spanish Jesuit architect Juan Bautista Villalpando (15521608). Its contours were distinctly echoed in the mid-1640s in the innovative architecture of Jacob van Campen's Nieuwe Kerk then under construction in Haarlem. In 1650, Leon Templo dedicated his Libellus effigiei Templi Salomonis to Spinoza's father, Michael de Espinoza (d. 1654), serving at the time as one of the Amsterdam Sephardic synagogue elders. ${ }^{16}$ Clear traces of this longstanding preoccupation with the iconic significance of Solomon's Temple are evident in Spinoza's Tractatus Theologico-Politicus where it is touched on repeatedly, in Willem Goeree's architectural theories, in Jan Goeree's engraving of Solomon's Temple for Van Leenhof of 1700, and especially in Van Leenhof's books.

Goeree's lifelong zeal for Hebraica and Jewish antiquities and his scepticism about Reformed theology doubtless owed much to his father and at least something to Rabbi Leon Templo. His fervour for research and study, especially into antiquities, and his profession as a bookseller-first in Middelburg and later in Amsterdam-led him to acquire a detailed knowledge of the books, prints, and book trade of his time and to become a man of substantial

14 Willem Goeree, 'Preface' to Petrus Cunaeus, République des Hebreux [French translation of his De Republica Hebraeorum (1617)], ed. Willem Goeree (Amsterdam, 1705) 2: fols. 3r, $6 \mathrm{v}-7 \mathrm{r}$; Mozes Heiman Gans, Memorboek: Platenatlas van het leven der joden in Nederland (Baarn, 1978), pp. 37, 103, 260.

15 Gerald Cerny, Theology, Politics and Letters at the Crossroads of European Civilization: Jacques Basnage and the Baylean Huguenot Refugees in the Dutch Republic (Dordrecht, 1987), pp. 200-1.

16 Van den Heuvel, 'Willem Goeree' (see above, n. 11), 156, 158; Gary Schwartz, 'The Temple Mount in the Lowlands,' in: The Dutch Intersection: The Jews and the Netherlands in Modern History, ed. Yosef Kaplan (Leiden, 2008), pp. 111-2, 114-5. 
learning in the vernacular. His compendious and ambitious Mosaize Historie der Hebreeuwsche Kerke (Mosaic History of the Hebrew Church, 1700) reflects a zeal for topics with wide implications and a range of radical influences besides that of Bekker. Over the decades, Goeree developed and refined his distinctive, challenging outlook blending religious heterodoxy with art and architectural theory, an outlook acquired not solely through books but also through his cultivation of the company of other freethinkers. Besides knowing Van den Enden personally, he became acquainted with numerous notable personalities in various Dutch cities. During his stays in The Hague - where he also seems to have known Christian Huygens - he enjoyed long discussions, he informs us, with Isaac Vossius, "whose courtesy and friendliness I cannot sufficiently praise."17 In 1677, the year after Momma's expulsion from Middelburg and the death of Spinoza at The Hague, and three years after Van den Enden's execution in Paris, Goeree transferred his shop and collection of architectural models-which, he tells us, he hoped would be seen and appreciated by others "tot nut van ' $t$ gemeene best" (for general edification)—permanently to Amsterdam. During the early 168 os his shop was situated on the Rokin; in or before 1683 he transferred his establishment to the house on the Leidsestraat located between the Keizers - and Prinsengracht, where he published Van Leenhof's Keten. ${ }^{18}$

Very likely the individual suspected of heterodox opinions alluded to by David van Hassel in his preface to the Dutch-language version of Christopher Wittichius's Anti-Spinoza published in 1695, in his native land Goeree was generally reputed to be a writer of suspiciously radical (and probably spinozist) views by the mid-169os, if not earlier. According to Van Hassel, no egg resembles another as much as Spinoza's philosophy resembles that of the Stoics, which this supreme modern impostor had disgracefully rehashed and served up as his own, ${ }^{19}$ though this had not at all deterred his insidious following, which included the dubious personage in question who was now exerting a deplorable influence. In any case, there can be little doubt of Goeree's religious heterodoxy during his later years. He was specified by name as a religious dissident and a rebel against ecclesiastical authority at the gatherings of the North and South Holland synods in 1703, and again by the North Holland Synod when it convened at Alkmaar in August 1704. On these occasions, he was cited for expressing Bekkerite views in his Mosaize historie, an impressively researched

17 Willem Goeree, Voor-Bereidselen Tot de Bybelsche Wysheid en gebruik der Heilige en Kerkelijke Historien, 2 vols. (Amsterdam, 1690), 1: 105.

18 Van Eeghen, Amsterdamse boekhandel (see above, n. 7), 4: 162.

19 David van Hassel, 'Voorreden' to Christopher Witichius, Ondersoek van de Zede-kunst van Benedictus de Spinoza (Amsterdam, 1695), pp. i-ix. 
and detailed account of early Israelite history illustrated with prints by Jan Luiken (1649-1712), which also caused a stir for its bold criticism of the way the Reformed Church had proceeded in the Balthasar Bekker affair. ${ }^{20}$

Like his son, a congenial lover of literary get-togethers and poetry as well as art, Willem Goeree was fond of combining learned conversation with meetings and conviviality. In one of his first publications, his Inleydinge tot de Algemeene Teyken-konst (Introduction to the Art of Drawing, 1668), he expressly looked forward to a more enlightened future age when "amateurs of learning" would be sufficiently numerous in each city and would be eager to gather for regular meetings as a college or literary society blending the arts and learning. ${ }^{21}$ Training artists should by no means be just a matter of teaching them how to draw from life and other technical skills; it should also encompass the acquisition and diffusion of historical understanding, along with conviviality, sociability, and debate. A recurrent theme of Goeree's writing is that men should strive not just for themselves but more especially for 't gemeene best, for "the common good," and, as the French translation of one of his works puts it, "l'utilité du prochain, et sur tout je crois que le bien public lui doit tenir au coeur préférablement à toute autre chose."22

Arnold Houbraken (1660-1719), for his part, possessed an unrivalled knowledge of which artists had studied with whom, were friends of whom, and had travelled abroad with whom. He, too, knew personally not only many artists and art dealers but also several prominent Reformed theologians, including Salomon van Til, whose treatise on classical and ancient Hebrew poetry and song, published in Dordrecht in 1692, he illustrated with several engravings, and David Fludd van Giffen, whose portrait he painted and whose collection of curiosa he reports on in his Groote Schouburgh. ${ }^{23}$ Houbraken lived much of his life in Dordrecht, where he had studied art in the years $1674-8$ with "SvH," as he calls him in his Philalethes Brieven, that is Samuel van Hoogstraten (1627-78), whose views on painting and painters became a key stimulus to his own career both as an artist and as a writer on art, and by whom there is a portrait, painted

20 Acta North Holland Synod, Noord Hollands Archief, Haarlem, Provinciaal Kerkbestuur van Noord-Holland van de Nederlands-Hervormde Kerk, inv. nr. 8, acta Edam 31 July/ 9 Aug. 1703 and acta Alkmaar July/Aug. 1704.

21 Wijnand Meinhardt, Tot heil van 't menschdom (Amsterdam, 1987), p. 82; Simon Schama, Rembrandt's Eyes (London, 1999), p. 517; Taylor, Dutch Flower Painting (see above, n. 3), pp. 79, 88-9.

22 Goeree, 'Preface' to Cunaeus, République des Hebreux (see above, n. 14), 2: fol. 1r.

23 [Arnold Houbraken], Philalethes Brieven. Verzameling van uitgelezene keurstoffen handelende over den godsdienst, natuur-, schilder-, teken-oudheid-, redeneer-en dichtkunst, 2nd ed. (Amsterdam, 1713) [hereafter [Houbraken], PB], p. 4. 
in 1670, thought by some modern researchers (probably incorrectly) to be of Spinoza. Hoogstraten was the first Dutch writer on art to explicitly set up a hierarchy of genres, ranking depictions of physical objects and still lifes as his lowest category and, as his highest level, paintings "which show the noblest emotions and desires of those creatures which are rational, that is, of human beings; and because these are subjects with more than merely the power of animal motion, so the artists who have a true capacity for this style of painting are spread the thinnest."

Houbraken was a dedicated realist and naturalist, albeit not exactly in our twenty-first-century sense. Like Goeree, he shared a theory of art that heavily stressed realism in a wider context than just physical representation, one that applauded art that captured accurately and emphasized houding - 'pose,' truthful reflection of movement, posture, positioning, and response and that eschewed the false, magical, and irrational. Among the lessons Houbraken professed to have learnt from Van Hoogstraten - and a key to his notion of good judgement in artistic matters-was that the artist should always strive "om waarheden te verthoonen" (to convey truths). Wherever the artist fails in this, he falls short and is reprehensibly helping perpetuate and propagate "false ideas." ${ }^{24}$ Hoogstraten was enthralled by acting and the theatre and constantly strove to get his students to observe and study the outward expression of emotion. He was like Goeree, who insisted on the need for naturalness of bodies, light, gesture, and perspective in drawing and painting, even designating accurate drawing "de Baer-moeder, en voester aller consten en wetenschappen" (the womb and wet-nurse of all arts and sciences). ${ }^{25}$

Houbraken laid an unusual stress on the need to devise ways to represent complex human scenes in a rational manner so as to meaningfully reflect the play of intention, motive, and emotion. He was greatly impressed with Romeyn de Hooghe's inventiveness and originality in matters artistic (not just in drawing and etching but also painting), despite his reservations about de Hooghe's character. ${ }^{26}$ Likewise, he admired Rembrandt for widening the range of facial expressions, gestures, and attitudes in art, though he also criticized the artist

24 [Houbraken], $P B$ (see above, n. 23), pp. 3-4; Svetlana Alpers, Rembrandt's Enterprise: The Studio and the Market (Chicago, 1988), pp. 24, 38; 95; Horst Gerson, Rembrandt's Paintings (New York, 1968), p. 48; Ernst van de Wetering, Rembrandt: The Painter at Work (Amsterdam, 2000), pp. 150, 169, 175, 179, 255, 282, 353.

25 Willem Goeree, Inleydinge Tot de Al-ghemeene Teycken-kunst (Middelburg, 1668), fol. 4v; Paul Knolle, 'Een goede kunstwerk-plaats: De Haarlemse tekenschool,' in: Romeyn de Hooghe (see above, n. 4), pp. 184-9, there 187.

26 Huigen Leeflang, 'Waarheid, vlugheid en inventie,' in: Romeyn de Hooghe (see above, n. 4), p. 127 . 
as someone who could have been greater had he put more smooth finish and care into his works. Art studies and tuition in Rembrandt's studio, Houbraken learnt from Hoogstraten and other former Rembrandt pupils that he knew, involved drawing nudes from life: a positive thing in the main, but he wished the great master had represented fewer naked women with fat bellies and sagging breasts, a form of realism he considered excessively physical and lifelike and insufficiently linked to expression and meaning.

Rembrandt had shown more patience, he thought, and had better captured the natural expression of human gesture and movement during his early years as a painter than he did later and had displayed greater expressive power. Rembrandt took no notice, Houbraken remarked, of even the most generally approved rules in art "but took his own opinion for his rule." For the paintings of his contemporary, the Rotterdam painter Adriaen van der Werff (1659-1722), by contrast, Houbraken expressed unqualified admiration, praising especially his highly polished, elevated painterly technique which to his mind placed Van der Werff amongst the finest Dutch artists. For Houbraken, projecting 'truths' evidently meant depicting subjects in an elevated, polished, classicizing manner without placing them in an unnatural or unhistorical context or milieu. His was an art theory stressing harmony, realistic posture, and the narrative logic of positioning and composition. For both Houbraken and Goeree, as for Van Hoogstraten earlier, art was not far from being a narrative science of emotion based on the close observation and study of posture and movement.

If Houbraken was unrivalled in his detailed knowledge of the lives and characteristics of Dutch artists, Goeree seems to have been widely respected, particularly in Middelburg and Amsterdam, for his wide-ranging erudition. Given their quantity and sometimes expensive format, his own published writings appear to have sold fairly well even if they were only sparsely cited in the scholarly literature of his time (and later). As the spinozist novel Philopater mockingly noted in 1697 , his vernacular texts proved useful not least to learned preachers when preparing their sermons. ${ }^{27}$ Doubtless his erudition was scorned by Latin-trained professional scholars of the age owing to his lack of any formal academic background, but his works are by no means uninteresting, even today. He did not hesitate to accuse professional theologians of lacking adequate expertise and betraying an inadequate knowledge of Hebrew-a language he vigorously championed and to which he claimed to have devoted a lifetime of study. Like Van Leenhof, ${ }^{28}$ he accused the clergy of claiming a

27 [Johannes Duikerius], Het Leven van Philopater, ed. Gerardine Maréchal (Amsterdam, 1991), p. 119 .

28 Jonathan Israel, 'Religious Toleration and Radical Philosophy in the Later Dutch Golden Age (1668-1710),' in: Calvinism and Religious Toleration in the Dutch Golden Age, ed. Ronnie 
false authority on the basis of qualifications they did not possess. He especially charged professional theologians with ignorance of ancient history, Jewish and Gentile alike, and of antiquities. ${ }^{29} \mathrm{His}$ supreme offence in the eyes of Reformed ministers was his scornful rejection of the idea that theology and Bible study, and religious truth generally, constituted a fenced-off professional precinct, a speciality reserved for trained theologians. This was a conviction Houbraken fully shared and in both cases their heterodox theology and contempt for academic theologians were closely linked to their art and art theories.

Theology, Goeree echoed Cunaeus' scathing judgement of the professional theologians, was "un pais qu'ils se sont appropriez de leur propre autorité, pour y exercer une domination absolue, et une dictature souveraine." ${ }^{30}$ He robustly defended Bekker's bold stance on witchcraft, Satanism, and demonism and his style of scriptural exegesis. ${ }^{31}$ Insisting on the fraudulent character and powerlessness of the Egyptian magicians recounted in the Pentateuch, he repeatedly asserts that sorcery and magic do not really exist. ${ }^{32}$ Moreover, in his views on miracles, magic, and the Devil, Goeree goes noticeably beyond Bekker, referring to the Devil seemingly more in the spirit of Koerbagh than his Frisian hero as essentially simply human desire, a force at war "with reason and goodness" in the human soul that cannot be driven out of any human being except by death. ${ }^{33} \mathrm{He}$ approvingly quotes Hobbes on the subject of the Devil, which Bekker had certainly not done, ${ }^{34}$ and he enthusiastically adopts Anthonie van Dale's radical perspective on ancient oracles and the impostures of the ancient priesthood. ${ }^{35}$ Following Van Dale, he dismisses the Sibylline Books as totally fraudulent and in no way a prophecy of the coming of Christ. ${ }^{36}$ Contrary to the Church Fathers, he contends that the pagan oracles continued to flourish "for around 400 years after Christ's birth" and did not cease through any supernatural agency, much less the coming of Christ, but were suppressed only

Po-Chia Hsia and Henk van Nierop (Cambridge, 2002), p. 154.

29 Willem Goeree, Mosaize Historie der hebreeuwsche kerke, 4 vols. (Amsterdam, 1700) [hereafter: Goeree, $M H$ ], 2: fols. 8r-9r.

30 Goeree, 'Preface' (see above, n. 14), 1: fol.

31 Goeree, $M H$ (see above, n. 29), 2: fol. 619-620; Willem Goeree, De Kerklyke en Weereldlyke Historien (Amsterdam, 1705) [hereafter: Goeree, $K W H$ ], pp. 678-81.

32 Goeree, $M H$ (see above, n. 29), 2: fols. 1v-2r and 3: 126-7, 137-9.

33 Goeree, $M H$ (see above, n. 29), 2: 649-50, 687-93.

34 Goeree, $M H$ (see above, n. 29), 2: 656 .

35 Goeree, $M H$ (see above, n. 29), 1, sig. k2r and 2: fol. 2r; [Houbraken], $P B$ (see above, n. 23), 1: 164-5; see also Eric Jorink and Dirk van Miert, 'Epilogue: Isaac Vossius in Context,' in: Isaac Vossius (1618-1689): Between Science and Scholarship, ed. Eric Jorink and Dirk van Miert (Leiden, 2012), p. 314.

36 Goeree, $M H$ (see above, n. 29), 2:667; Jonathan Israel, Enlightenment Contested:Philosophy, Modernity, and the Emancipation of Man 1670-1752 (Oxford, 2006), 429. 
due to decrees passed by the Emperor Theodosius and his sons, Arcadius and Honorius. ${ }^{37}$ He cheerfully ridiculed Bishop Huet's strenuous efforts to rescue the Church Fathers on this topic.

Explaining all supposedly demonic and magical phenomena narrated in Scripture in naturalistic terms, Goeree regularly dismisses 'possession' by devils as recounted in the New Testament as mere incidents of mental illness, fits, and madness. ${ }^{38}$ During the discussions about "licentious book printing" at the gatherings of the Reformed Synod of South Holland at Gorcum in July 1703 and of the Province of Overijssel at Steenwijk in May 1704, extracts from the "last book of Goeree" were examined "waer in hy de gevoelens van Balthasar Bekker niet alleen met veel vrymoedigheit verdedigd, maer besonder ook de Synodus van Noord Holland over het removeren van voornoemden Bekker van syn predikdienst uitkrijt voor een voldoeninge van wraakheyt, om maer dien hupsen man van den cansel te schoppen, en meer andere" (wherein he not only defends the opinions of Balthasar Bekker with great boldness, but in particular decries the Synod of North Holland for having removed the said Bekker from his ministry to satisfy their vengefulness, just to kick this good man from the pulpit). ${ }^{39}$

Indignant at Goeree's impieties, delegates from the South Holland Reformed Synod had consulted the pensionary of the States of Holland, Anthonie Heinsius, about ways and means to suppress "this and other licentious books." At the time, Goeree was reportedly residing in the village of Maarssen in the province of Utrecht. The South Holland Reformed Synod gathering at Den Briel in July 1704 noted that Heinsius had also been asked to intercede with the States of Utrecht against Goeree, and the Utrecht "correspondent" confirmed that his provincial synod had indeed now presented a "request" to their provincial States to take action to counter Goeree's "harmful" ideas and damaging presence in their province. ${ }^{40}$ The Synod of Overijssel was asked to inform

37 Goeree, $M H$ (see above, n. 29), 2:662-5; Jonathan Israel, Radical Enlightenment:Philosophy and the Making of Modernity 1650-1750 (Oxford, 2001), pp. 363-4, 428.

$3^{8} \quad$ Goeree, $M H$ (see above, n. 29), 1: 22 and 2: 688.

39 Acta South Holland Synod, Het Utrechts Archief (HUA), Oud-synodaal Archief van de Nederlandse Hervormde Kerk (OSA), inv. nr. 265, acta Gorcum, 3/13 July 1703, art. 9; Acta Synod of Overijssel, Historisch Centrum Overijssel (HCO), Zwolle, Archief van de provinciale synode van Overijssel (APSO), inv. nr. 3, acta Steenwijk, 27 May art. 6 licentieus boekdrukken'; Jonathan Israel, 'The Bekker Controversies as a Turning-Point in Dutch Culture and Thought,' Dutch Crossing: A Journal of Low Countries Studies 20 (1996), 5-21, there, 10-11; Jacob van Sluis, Bekkeriana: Balthasar Bekker biographisch en bibliographisch (Leeuwarden, 1994), p. 71.

40 Acta South Holland Synod, HUA, OsA, inv. nr. 265, acta Den Briel, 8/18 July 1704 art. 23; Goeree, $M H$ (see above, n. 29), 1: fol. 2r; 2: fols 1v-2r. 
the States of Overijssel's deputies in The Hague to help ensure that the political authorities kept an eye on him and that his "damaging opinions" were carefully guarded against. Curiously, Goeree's name was specifically linked in this discussion with 'New Arianism,' currently perceived to be a fresh theological threat. How exactly this 'new' Arianism related to original Arianism and Socinianism remains to be clarified.

At the meeting of the South Holland Reformed Synod at The Hague in July 1705, it was reported that Pensionary Heinsius had agreed to raise the issue of Goeree with the burgomasters at Amsterdam, where the suspect author had now removed himself and "sich nu aldaar seer stil hieldt" (now kept himself there very quiet), presumably to avoid trouble in light of the political and ecclesiastical surveillance and persecution directed towards him. ${ }^{41} \mathrm{He}$ had no intention, though, of abandoning the fight over demonology, Satan, Bekker, biblical interpretation, and related topics. His Kerklyke en weereldlyke historien (Histories of the Church and the World, 1705), which tellingly and probably provocatively included a portrait of Spinoza and which many years later in 1730 was quietly reprinted in Leiden, initiated a new phase in his escalating encounter with the Reformed synods and preachers. ${ }^{42}$ At gatherings of the South Holland Synod in 1706 and at the meeting at Leerdam in July 1707, the Delft delegates complained about his latest outpouring of irreverence and theological subversion wherein, just as in his Mosaize historie, "vele aanstootelijk en ergelycke passagien worden gevonden, waar in de gevoelens van Bekker, ja noch snoder wel stout en stijf worden beweert" (many shocking and offensive passages are to be found, in which the views of Bekker are boldly and forthrightly, indeed even more vilely upheld) and the Church's official proceedings against the dissident Frisian preacher were openly mocked. ${ }^{43}$

Like Houbraken, Goeree verged on excluding the supernatural and all notions of the divine as being altogether separate from nature. He came close to affirming that the Ten Plagues were not an instance of divine intervention or any kind of miraculous occurrence but rather were explicable purely in terms of natural causes. ${ }^{44}$ In the case of the parting of the waters of the Red Sea, he does not entirely rule out the possibility of supernatural intervention but considers it incumbent on any responsible commentator on that 'miracle' to research

41 Acta South Holland Synod, HUA, OSA, inv. nr. 265, acta 's-Gravenhage 7/17 July 1705, art. 24.

42 Acta South Holland Synod, HUA, OSA, inv. nr. 265, acta Leerdam 1707, art. 18; Goeree, $M H$ (see above, n. 29), 1: sig. k2r and 2: fols 1v-2r; G. Maréchal, 'Inleiding' to Johannes Duijkerius, Het Leven van Philopater en Vervolg van 't Leven van Philopater (Amsterdam, 1991), p. 44 and plate 7 .

43 Goeree, $M H$ (see above, n. 29), 3: 143.

44 Goeree, $M H$ (see above, n. 29), 3: 345-9. 
the likelihood of earth tremors, the role of shallows, and the movement of tides in order to exhaustively examine every conceivable natural explanation. ${ }^{45}$ Superstition and belief in demons and sorcery Goeree ranks among the worst curses afflicting humanity, because manipulative priesthoods have regularly exploited popular credulity, demonology, and idolatry to enhance their power and exact obedience. 46 "Why," he asks, "did the Saviour not vigorously combat and contradict all these gross errors?" ${ }^{\prime 7}$ He repeatedly laments that Christ and the Apostles made no attempt to counter the superstitious beliefs of the people of their time, especially regarding demonology. Regrettably, he observed, Christ himself "sometimes used phrases accepting the teaching of demons and power of possession." Against the background of his consistent anti-Trinitarianism, this remark implies a stance coloured by Spinoza's idea that Christ and his Apostles, using phrases expressing the credulous beliefs of the common people, were concerned only to teach the people obedience to the moral code, remaining unconcerned with enlightening men, uncluttering their minds, or propagating truth. 48

Typical of Goeree's general stance is his undisguised disdain for the VoetianCocceian and other contemporary theological controversies within the public Church, which he considered irrelevant to men's lives. At one point, he comments - with studied irony - that he does not consider that "ceux qui s'érigent en dictateurs des mistères sacrez" perform this role cogently or persuasively enough to oblige those who feel themselves "munis d'une conscience droite et éclairée, et dont les moeurs et la vie sont irreprochables, à se soumettre entièrement à ce qu'il leur plaît de décider."49 Men of genuine learning and goodwill should remain pure "spectateurs de leurs combats," the feuding of rival theologians being more a matter of ambition and petty jealousy than theology. Readers should ponder these debates "sans y prendre part, sinon en ce que nous faisons des voeux et des prières pour la cause publique, et éloignez de la folle multitude;" the wise when having the leisure should devote themselves exclusively to the authentic, purposeful study of theology, not to "cette théologie de parti, mais à une theologie sobre, modeste, libre, fondée sur la litérature soit grecque, soit Hebraique, soit Latin, dégagée de toute animosité, et de toute querelle, que nous faisons profession de fuir et de mépriser." 50

\footnotetext{
45 Goeree, $M H$ (see above, n. 29), 2: 685-7.

46 Goeree, $M H$ (see above, n. 29), 1: 23 and 2: 688.

47 Goeree, $M H$ (see above, n. 29), 2: 688, 702; [Houbraken], $P B$ (see above, n. 23), 1: 119-20, $125,128-30$.

48 Goeree, 'Preface' to Cunaeus, République des Hebreux (see above, n. 14), 1: 9.

49 Goeree, 'Preface' to Cunaeus, République des Hebreux (see above, n. 14), 1: 9.

5o Nagtglas, Levensberichten van Zeeuwen (see above, n. 13), 1: 271.
} 
Although he seems to have mostly resided in Middelburg down to 1677,51 Goeree must have spent periods in The Hague and Amsterdam well before moving to the latter permanently, having got to know Van den Enden "very well" 52 at some point before the notorious ex-Jesuit left Amsterdam for Paris in $1671 .{ }^{53}$ Migrating from Antwerp at the close of the Eighty Years' War, around 1648, Van den Enden had opened a shop in the Nes selling prints and books. After only about five years, his Amsterdam art business had gone bankrupt in $165^{2}$ at the start of the First Anglo-Dutch War (1652-4), which also ruined the business of Spinoza's father. At the time of his bankruptcy, Van den Enden still had thirty paintings and a large quantity of prints and unsold books in stock. ${ }^{54}$ Before 1648, he had participated in the art trade in Antwerp, producing and selling prints together with his brother, Martinus van den Enden. ${ }^{55}$ At least one of Rembrandt's pupils had lodged with Van den Enden in Amsterdam in or around 1652 , a time when several talented young trainees in their late teens, Willem Drost (1633-59) among them, ${ }^{56}$ were crowding Rembrandt's 'school.' Although Drost was too young to have known Goeree when he ran his art shop in the Nes, it is not impossible that common ties to the art world shaped Goeree's later connection with him.

That both men knew a great deal about the Amsterdam art scene may well have framed their mutual acquaintance, ${ }^{57}$ even if, on the subjects of Van den Enden and Koerbagh, Goeree offered only unflattering and disapproving remarks in print. Having, he records, as a young man "more than once eaten and drunk with" Van den Enden, he had learnt little that was edifying and was not surprised that "Spinoza too picked up few good principles from this master who was very generous in peddling his godless convictions to young and old alike, and boasting that he was rid of the fable of faith." 58 Taking up the profession

\footnotetext{
$51 \quad$ Goeree, $K W H$ (see above, n. 31), p. 669.

$5^{2}$ Marc Bedjaï, 'Libertins et politiques: le comte de Guiche', Revue de la Bibliothèque Nationale 44 (1992), 29-33, here p. 32.

53 Wim Klever, 'Inleiding' to Franciscus van den Enden, Vrije Politijke stellingen en consideration van staat (Amsterdam, 1992), pp. 17-9; Steven M. Nadler, Spinoza: A Life (Cambridge, Eng., 1999), pp. 78-9.

54 Frank Mertens, Van den Enden en Spinoza (Voorschoten, 2012), pp. 10-29.

55 Jonathan Bikker, Willem Drost (1633-1659): A Rembrandt Pupil in Amsterdam and Venice (New Haven, Conn., 2005), p. 10.

$56 \quad$ Klever, 'Inleiding' (see above, n. 53), p. 18.

57 Goeree, $K W H$ (see above, n. 31), p. 665; Koenraad O. Meinsma, Spinoza et son cercle (Paris, 1984), pp. 5, 192; Rienk H. Vermij, 'Dirk Santvoort, een achttiende-eeuws materialist,' Geschiedenis van de wijsbegeerte in Nederland 11 (2000), 61-80, there $67 \mathrm{n}$.

$5^{8}$ Fokke Akkerman, Studies in the Posthumous Works of Spinoza (Groningen, 1980), pp. 3, 18 n. 12; Klever, 'Inleiding' (see above, n. 53), pp. 21-3.
} 
of schoolmaster after 1652, Van den Enden devoted much energy to teaching his pupils good Latin style, requiring them to perform the plays of Seneca and Terence in the original. But it was also his practice, until ugly rumours spread about it, to inculcate his atheistic ideas into the young..$^{59}$ Adriaan Koerbagh, too, observes Goeree, "through contact with this man did not imbibe anything good [...] as is plain from all those offensive entries in his Dictionary, or stinking Bloemhof." 60

By contrast, his passages concerning Spinoza (whom Goeree may also have known) are by no means as disapproving and hostile as was then the rule in respectable Dutch intellectual discourse. Indeed, certain remarks allow the hypothesis that his sympathies and ideas bore a spinozist flavour. In any case, both he and Houbraken display a fairly comprehensive knowledge of radical thought; their testimonies show that both men had read Spinoza, Koerbagh, Bekker, and Van Leenhof. Theirs was a cultural and intellectual world that encompassed Geulincx, Vossius, Van Dale, Wittichius's Anti-Spinoza,${ }^{61}$ Wolsgryn, Simon, Bayle, Hobbes, ${ }^{62}$ Van Leenhof, and also Van Balen. ${ }^{63}$ Goeree seems to have pondered Spinoza's account of substance and the doctrine of the parallelism of mind and body discussing this problem and Spinoza's treatment of it in one passage in his works. ${ }^{64}$ Of course, no writer in the United Provinces in the eighteenth century could openly endorse Spinoza or spinozism. Goeree does pay lip service to the usual denunciation of him as an 'atheist' and decries a spinozist novel, the second part of Philopater published by Aert Wolsgryn at Amsterdam, in 1697, a cornerstone of Dutch popular spinozism, as a book in which the "deadly weed" produced by Spinoza, that verdwaalden filozoof (philosopher gone astray), came to full bloom. ${ }^{65}$

Yet there is plainly another side to the picture. A remarkable passage in his world history concerns the medieval scholastic philosopher Peter Abelard (1079-1142), based apparently on the article in Bayle's Dictionnaire where Bayle cites Abelard as a courageous early example of the resort to philosophical reason, the "lumières philosophiques" which, he implies, had "enlightened"

59 Goeree, $K W H$ (see above, n. 31), p. 665; Meinsma, Spinoza et son cercle (see above, n. 59), pp. 192, 381-2; Israel, Radical Enlightenment (see above, n. 38), p. 168.

6o Goeree, $K W H$ (see above, n. 31), pp. 5, 667 .

61 Willem Goeree, Natuurlijk en Schilderkonstig Ontwerp der menschkunde (Amsterdam, 1682), pp. 359-6o; Goeree, KWH (see above, n. 31), p. 5; Goeree, Voor-Bereidselen (see above, n. 17), 1: 150 .

62 Goeree, $K W H$ (see above, n. 31), pp. 674-5; [Houbraken], $P B$ (see above, n. 23), 2: 2, 64-5.

63 Goeree, Voor-Bereidselen (see above, n. 17), 1: 105.

64 [Houbraken], $P B$ (see above, n. 23), 2: 83; Maréchal, 'Inleiding' (see above, n. 43), p. 36.

65 Goeree, $K W H$ (see above, n. 31), p. 562; Israel, 'Democratic Republicanism' (see above, n. 7 ), p. 280. 
(éclairé) the seventeenth century and rescued humanity from monkish superstition and ignorance. ${ }^{66}$ The passage in Goeree illustrates the pervasive role that philosophical reason, and especially Spinoza's philosophy, played in his thinking. Abelard, he affirms, imbibed errors concerning the Trinity and denied both Christ's divinity and his being the Saviour who had come into the world and had become flesh to redeem sinners, holding, like Van Leenhof, that Christ's crucifixion and death did not constitute a work of redemption "maar tot een voorbeeld van gedult dat wy moesten volgen. Hy leerde dat de mensch geen vrye wil heeft, maar dat hy neffens alle dingen, ja Godt zelve, de noodzakelijkheid onderworpen is" (but just an example of patience which we were to follow. He taught that a person has no free will but rather, like all things, yes even God, is subject to necessity). ${ }^{67}$ Abelard, as reported by Goeree, also taught that reason is the only guide in matters of faith. One perceives in Abelard, concludes Goeree, many things heaped up "die men 't thans Spinoza te last leyd" (that are now laid at Spinoza's door), a remarkable assertion made without any judgement, positive or negative, or further comment.

Although the herem (ban) imposed by the synagogue on Spinoza was uniquely harsh, and indeed according to Goeree in 1690 (who, on this point, is subsequently cited by Colerus, in his biography of Spinoza) entirely out of line with normal Jewish practice, ${ }^{68}$ Spinoza's departure from the synagogue should nevertheless be attributed less to Jewish intolerance than to his wish "om zig van allerley gewetensdwang en sekten-aanhang los te maken, en een vrye geest te verkrijgen" (to free himself from all forcing of conscience and allegiance to sects, and to be a free spirit). ${ }^{69}$ In another comment, Goeree claims the Jewish philosopher adhered consistently to his principles until he died in The Hague in 1677, showing no signs of weakening in his views, as one can see, he says, from François Halma's notes to his Dutch translation of Bayle's article on Spinoza, although these are "niet heel van Voor-oordeel vry zijn" (not entirely free from bias), a qualification again suggesting dissent from Halma's unqualified anti-spinozism..$^{70}$ Further on, repeating his assertion, reminiscent

66 Gregorio Piaia, 'Bayle et le moyen âge', in: Pierre Bayle dans la République des Lettres: Philosophie, religion, critique, ed. Antony McKenna and Gianni Paganini (Paris, 2004), p. 233.

67 Johann Colerus, Das Leben des Bened: Von Spinoza (Frankfurt and Leipzig, 1733), p. 22.

68 Goeree, $K W H$ (see above, n. 31), p. 666.

69 Goeree, $K W H$ (see above, n. 31), p. 666.

70 Pierre Bayle, Écrits sur Spinoza, ed. Françoise Charles-Daubert and Pierre-François Moreau (Paris, 1983), pp. 36-7, 113-14; Gianluca Mori, Bayle philosophe (Paris, 1999), pp. 158,165 . 
of the Bayle article in question, ${ }^{71}$ that Spinoza adhered to his views with great constancy to the end, he also follows Bayle in claiming that Spinoza's behaviour had been "geschickt, zedig, goed-aardig, vriendelijk, beleefd en gedienstig" (decent, modest, good-natured, friendly, courteous, and obliging), citing here the reference to Spinoza in Bekker's sequel to Hornius's church history.72

Goeree's most telling assertion concerning Spinoza, however, is his claim that in the Netherlands at the time, the latter's ideas were not being fairly considered. He characterizes Spinoza's goal to have been the dislodging from the minds of "both Jews and Christians all grounding of true religion and belief and to make known that religion was invented merely for political reasons, that is to keep society in tranquillity and the people in subjection." Spinoza had allegedly already set out on this quest in that "unknown work," the DeJure Ecclesiasticorum (1665) (a publication now considered possibly to be by his friend and ally Lodewijk Meyer). ${ }^{73}$ The rest of Spinoza's ideas, holds Goeree, one must retrieve from his books "en 'er niet eer veel van na-praten, voor dat men ze in den grond onderzogt heeft;' $t$ geen misschien weynige nog ter deugde gedaan hebben" (and not prattle about them too much before having studied them thoroughly; which few perhaps have done properly). ${ }^{74}$

This last remark is an unmistakable hint that he thought readers should examine and judge Spinoza's writings for themselves and also suggests that he believed that he himself had studied Spinoza carefully, whereas most of those who loudly condemned Spinoza had not-as was doubtless the case. Borrowing their views too readily from other people, many had thus "al te voorbarig" (all too rashly) assumed Spinoza to be a muddle-head. Such superficial reading and criticism was, in his opinion, both reprehensible and foolish. In short, Goeree disliked and courageously denounced the conventional anti-spinozism saturating the Dutch culture of his day. He seems to have thought that those spinozists "die altyd roepen dat men hem qualyk verstaat" (who always protest that he is wrongly interpreted) had more than a little justification for their view. ${ }^{75}$

A further indication of Goeree's hostility to religious authority and his broadly radical leanings lies in his remark that those few who have undertaken serious study of Spinoza's philosophy “zeggen, dat hy veel goede dingen heeft,

71 Goeree, $K W H$ (see above, n. 31), p. 668; see Manfred Walther (ed.) Die Lebensgeschichte Spinozas: Zweite, stark erweiterte und vollständig neu kommentierte Auflage der Ausgabe von Jakob Freudenthal (2 vols., Stuttgart-Bad Cannstatt, 2006) i, 107 and ii, 65.

72 Goeree, $K W H$ (see above, n. 31), p. 666.

73 Goeree, $K W H$ (see above, n. 31), p. 669.

74 Goeree, $K W H$ (see above, n. 31), p. 670.

75 Goeree, $K W H$ (see above, n. 31), pp. 670-1; Israel, 'Democratic Republicanism' (see above, n. 7$)$, pp. $274,276$. 
en zelfs Kartesius in vele deelen verbeterd heeft. Dog zulx te zeggen schynd thans verbode taal" (say that he offers many good things, and in many sections has even improved on Descartes; though to say this today seems to be forbidden language) ${ }^{76}$ This comment plainly alludes to the current furore surrounding Van Leenhof, who was lambasted for suggesting that good as well as bad things were to be found in Spinoza's writings and that a particularly welcome and valuable aspect of Spinoza's teaching was his unrivalled analysis of how emotions work- a philosophical topic of special relevance, of course, to artists, art critics, and art students. It was commonly frowned upon to refer to Spinoza in such terms, complains Goeree, "alhoewel 'er den Heer Oldenburg nog Wittig niet beschroomd voor waren, hoe kragtig den laatsten zig nogtans tegen zyn Zedekunst en Beschryving van God heeft aangekant" (although neither Mr Oldenburg, nor Wittichius, were timid about saying so, however forcefully the latter nevertheless opposed his Ethics and account of God). ${ }^{77}$

Nor did the various available rebuttals of Van Leenhof's Den Hemel op Aarden (Heaven on Earth, 1703) in any way reflect, in Goeree's opinion, an adequate grasp of Spinoza's philosophy. ${ }^{78}$ That Goeree considered Van Leenhof a second Bekker and likewise sympathized with him, as well as endorsed his moral teaching, ${ }^{79}$ emerges from a passing mention of the Zwolle predikant in his De Kerklyke en Weereldlyke Historien, where he suggests that the author of the Betoverde Weereld (Balthasar Bekker) deserved a "far better fate" than he had received from the Dutch Reformed synods, pointedly adding that as regards Van Leenhof he preferred to pass by that delicate topic with a "silent drum." 80 It is fair to assume that he felt indignant at the public scandal being whipped up by the Reformed preachers and synods against Van Leenhof but deemed it advisable not to labour the point in print.

Houbraken evidently believed that he shared Goeree's philosophical and theological views as well as his artistic and other cultural concerns. This emerges unmistakably from the text of his clandestinely published Philalethes Brieven (1711), among the most radical Dutch publications of the early eighteenth century, an anonymously published work that appeared in the wake of the Van Leenhof controversies and that for a time I, along with other scholars,

$76 \quad$ Goeree, $K W H$ (see above, n. 31), 671.

77 Goeree, $K W H$ (see above, n. 31), pp. 674-5; Israel, 'Democratic Republicanism' (see above, n. 7), pp. $273-4$.

78 Goeree, $K W H$ (see above, n. 31), 37.

79 Goeree, $K W H$ (see above, n. 31), 37; [Houbraken], Philalethes Brieven (see above, n. 23), 1: $175^{-6 .}$

8o [Houbraken], $P B$ (see above, n. 23), 1: 6. 
had wrongly attributed to Goeree.$^{81}$ Such was the uproar that this publication provoked in the Netherlands that in 1713, pressure from the Amsterdam Reformed consistory apparently forced Houbraken to take refuge in England for several months. That Houbraken himself was perfectly conscious of his intellectual affinities with Goeree is apparent from a pointed remark in his preface that describes Goeree as "een schryver die by my in groote waarde gehouden word" (a writer who is held in high esteem by me). ${ }^{82}$

Philalethes Brieven reworks many of the same broadly anti-demonic, antiTrinitarian, spinozist, and Bekkerite themes and doctrines that Goeree advances in his two major controversial works. To Houbraken it seemed obvious that there exists no scriptural basis for the dogma of the Trinity. ${ }^{83}$ The precise mission of Christ and the Apostles was to correct and improve the people's behaviour but, unfortunately, they proceeded in this regard without seeking to combat their ignorance, credulity, and damaging superstitious ideas, all of which were left intact and untouched. ${ }^{84}$ Either at God's command or through his adroit grasp of politics, Moses, too, had adjusted his teaching and legislation to the people's superstitious and credulous mentality, aligning his rhetoric with their delusions, visions, oracles, dreams, and soothsaying. ${ }^{85}$ As for the classical Greek and Roman oracles and soothsayers, these he dismisses as altogether fraudulent, designed to exploit popular superstition and credulity. ${ }^{86}$ While it is certain that Moses did not write the Five Books - as others, including Petrus van Balen (1643-90), had shown, notes Houbraken, referring to the Rotterdam crypto-spinozist ${ }^{87}$ - the Pentateuch was nonetheless also built on the credulity and false notions of the people. ${ }^{88}$ At the same time, he professed, with an ironic flourish, to be championing the Five Books' sanctity and truth against the insidious arguments of "B. de Spinoza" and shielding its divine inspiration from the "blasphemies" of Hobbes, "Brown," and the author of the perfidious Philopater whom, like Goeree, he takes to have been Aert Wolsgryn (1656/7-after 1698), the Amsterdam bookseller and spinozist arrested in 1698

81 [Houbraken], $P B$ (see above, n. 23), 1: 127; Israel, Radical Enlightenment (see above, n. 38), pp. 432,730 .

82 [Houbraken], $P B$ (see above, n. 23), 1: 119-20, 125; Israel, 'Democratic Republicanism' (see above, n. 7), 280.

83 [Houbraken], $P B$ (see above, n. 23), 1: 56, 71 .

84 [Houbraken], $P B$ (see above, n. 23), 1:164-5.

85 [Houbraken], $P B$ (see above, n. 23), 1: 254.

86 [Houbraken], $P B$ (see above, n. 23), 1: 55-6, 64; Israel, Enlightenment Contested (see above, n. 27), p. 429.

87 [Houbraken], $P B$ (see above, n. 23), 1: 42, 57, 73, 124, 126.

88 [Houbraken], $P B$ (see above, n. 23), 1: 254 . 
for his role in the composition of the Philopater text. ${ }^{89}$ For that offence and for selling that strictly forbidden book under the counter in Amsterdam, the magistrates sentenced Wolsgryn to a 4,00o guilder fine and eight years' imprisonment, to be followed by perpetual banishment from Holland.

Just as Goeree had, Houbraken extolls Bekker and Van Leenhof as true heroes. ${ }^{90}$ It was central to Houbraken's and Goeree's radical Enlightenment ideology that humanity has achieved considerable progress and has done so (at any rate since the Reformation) through advances in knowledge. Consequently, in "our days" there has been a "geheele te niet doening van de Heydensche bygeloovigheit, die de weerelt dus lang heeft betoovert gehouden" (a complete demolition of pagan superstition which until now kept the world enchanted). ${ }^{91}$ The crucial point for them was that erudition, philosophy, and science, diffused in the vernacular not least by the likes of Goeree and Houbraken themselves, had been transforming the world to their way of thinking in a positive and irreversible manner. Here art joined forces with philosophy and science. Two modern thinkers expressly praised for assisting humankind in its progress - that is, teaching people to think in a clearer, more real, and orderly manner-were Arnold Geulincx (1624-69) and Van Balen, the highly controversial Rotterdamer several times favourably referred to by Houbraken. The result of this transformative process of enlightenment - and underlying it, the clandestine support for men like Bekker and Van Leenhof in lay societyis that "alle waarheid eindelijk openbaar wordt" (all truth finally is becoming manifest) and hence accessible. ${ }^{92}$

Convening at Schoonhoven in July 1712, the South Holland Synod was the scene of vehement complaints regarding this new, anonymously published, subversive text. ${ }^{93}$ At the gathering of Gelderland's synod at Nijmegen the following August, the South Holland delegate submitted a file of extracts from the offending work printed at Amsterdam, a book in which "Bekker, Leenhof, Hattem and [John] Spenserus are defended in their views and where malicious propositions contra Trinitatem" abounded. ${ }^{94}$ The following year, in 1714, the South Holland Synod was told that their standing committee had seen the pensionary of Holland, Heinsius, who, armed with a file of the most offensive

89 Michiel Wielema, The March of the Libertines: Spinozists and the Dutch Reformed Church (1660-1750) (Hilversum, 2004), pp. 89, 92.

9o [Houbraken], $P B$ (see above, n. 23), 1: 5, 42, 57, 73, 124.

91 [Houbraken], $P B$ (see above, n. 23), 1: 126.

92 [Houbraken], $P B$ (see above, n. 23), 1: 64, 127, 131, 176, 253-4.

93 Acta South Holland Synod, HUA, OSA, inv. nr. 266, acta Schoonhoven 5/15 July 1712, art. 13.

94 Acta Synod of Gelderland, Gelders Archief (GA), Arnhem, Archief van de Nederlandse Hervormde Kerk, Synode van Gelderland te Arnhem (ANHK/SGA), inv. nr. 13, acta Nijmegen, 1712, art. 5 'licentieus boekdrukken.' 
extracts, was now reviewing the problem of (theologically) seditious books and "in particular the dreadful opinions of Philalethes" with colleagues of the States. ${ }^{95}$ The Synod of Gelderland, similarly reviewing the "appalling views of Philalethes," gathered further extracts, noting especially passages expressing scepticism about demons and angels or sympathy for Van Leenhof. ${ }^{96}$ In August 1714, the Gelderland Synod learnt that the Amsterdam Reformed consistory had now at last 'discovered' the clandestine author's identity: the work had supposedly been written by a certain Samuel Mason, a preacher of the English church who had now, however, already fled to England. ${ }^{97}$

The Reformed Synod of Overijssel, meeting at Kampen in June 1714, heard from the South Holland delegate that Heinsius had assured his synod's standing committee that he would do everything possible to persuade the States of Holland to undertake a more energetic suppression of "licentious books" while targeting in particular Philalethes Brieven, the most offensive text currently under surveillance. ${ }^{98} \mathrm{~A}$ second edition of this subversive text, published in Amsterdam by Pieter Boetemans in 1712, was noted. Five specific charges against Houbraken's work were formulated in the synodal minutes: first, that the story of Adam and Eve being tempted by the serpent is dismissed by 'Philalethes' as a mere allegory of human desire not to be understood literally; ${ }^{99}$ second, the book endorsed the views of Van Leenhof and the so-called sect of 'Hebreen'; third, holy scripture is generally belittled and held in slight regard; fourth, Philaletes Brieven holds that nothing definite whatsoever regarding the Holy Trinity can be gathered from Scripture; ${ }^{100}$ fifth, the book categorically denies the existence of angels. ${ }^{101}$

A particularly striking feature of Philalethes Brieven is its binding together in a single compilation the milieu of Dutch radical thought with that of Golden Age art. 'Philalethes' continually weaves together the book's discussion of artistic matters, and the representation of reality in painting, with philosophical and theological issues. Among the prints embellishing the book is an illustration, presumably by Houbraken himself, representing Truth accompanied by Reason adorned with armour and a hero's helmet as well as a spear needed “to

95 Acta South Holland Synod, HUA, OSA, inv. nr. 266, acta Schiedam, 4/14 July 1713, art. 13.

96 Acta Synod of Gelderland, (GA), (ANHK/sGA), inv. nr. 13, acta Zutphen, 1713 art. 13 licentieus boekdrukken.'

98 Acta Synod of Overijssel, (HCO), (APSO), inv. nr. 3, acta Kampen, 5 June 1714, art. 6.

99 [Houbraken], $P B$ (see above, n. 23), 1: 5-7.

$100 \quad$ Houbraken], $P B$ (see above, n. 23), 1: 127.

101 Acta Synod of Overijssel, (HCO), (APSO), inv. nr. 3, acta Kampen, 5 June 1714, art. 6. 
protect Truth from oppression."102 The author boldly follows Goeree as well as the libertine Adriaen Beverland (1650-1716) in maintaining that Adam and Eve had not been seduced by the Devil in the form of a serpent and in claiming that this biblical episode in reality amounts to nothing more than an allegory for "begeerte tot het verboden" (desire for the forbidden). Satan did not adopt the guise of a serpent and, anyway, one must not interpret scripture literally. Strikingly, this sceptical message is reinforced with a print of 'Adam and Eve' conspicuously represented without a serpent being anywhere present, an illustration this time expressly designated as the work of Houbraken. ${ }^{103}$

The question has been raised in recent years whether evidence exists of ties connecting the vigorous Dutch spinozism that flourished in various Dutch cities in the 168 os and 169os, as manifested in the Dutch-language editions of the Tractatus Theologico-Politicus published in Amsterdam in 1693 and 1694 and the appearance of Aert Wolsgryn's sequel to Philopater in 1697, with the generation of subversive Huguenot and other spinozists in the Netherlands, men like Charles Levier, active in the years around 1720 and through the 1720 and ${ }^{1730 s .}{ }^{104}$ The evidence of the ferment caused by the censured books of Goeree and Houbraken during the opening years of the eighteenth century allows us to conclude that there was indeed such a cultural and intellectual continuity, and that among the notable links between the era of Van den Enden and Koerbagh and the eighteenth century's opening decades were two heterodox critics intimately connected with the art world of their day, Wilhemus Goeree and Arnold Houbraken, subversive intellects who deliberately and systematically propagated spinozist, Bekkerite, and Leenhovian ideas among artists' circles and more generally among the Dutch lay public. These two men have generally been neglected, and their significance for late Golden Age Dutch civic culture mostly missed, but it is fair to say that their lives and writings importantly illustrate one of the most formative and decisive transitions in early modern Dutch history.

\footnotetext{
102 [Houbraken], $P B$ (see above, n. 23), 1: 156.

103 [Houbraken], $P B$ (see above, n. 23), 1: 5 .

104 See in this connection, Wiep Van Bunge, From Stevin to Spinoza: An Essay on Philosophy in the Seventeenth-Century Dutch Republic (Leiden, 2001), pp. 149-62.
} 